J. Asiat. Soc. Bangladesh, Sci. 45(1): 45-54, June, 2019

\title{
EFFECTS OF SODIUM CHLORIDE SALINITY ON WATER RELATIONS AND ION ACCUMULATION IN TWO MUNGBEAN VARIETIES DIFFERING IN SALINITY TOLERANCE
}

\author{
MST. SHAHNAZ SULTANA ${ }^{1}$, M.A. HALIM ${ }^{1}$, FEROZA HOSSAIN ${ }^{1}$, \\ M. ABDUL KARIM ${ }^{2}$ AND MOHAMMAD TALIM HOSSAIN*1 \\ ${ }^{1}$ Department of Botany, Jahangirnagar University, Savar, Dhaka-1342, Bangladesh \\ ${ }^{2}$ Department of Soil Science, Faculty of Agriculture, Bangabandhu Sheikh Mujibur \\ Rahman Agricultural University, Salna, Gazipur, Bangladesh
}

\begin{abstract}
Salt tolerance in relation to water status and plant nutrients of two mungbean varieties, BARImung 2 (salinity sensitive) and BUmung 2 (salinity tolerant) was evaluated. The seeds were grown in pots and treated with $\mathrm{NaCl}$ levels of 0 (control), 100 and $200 \mathrm{mM}$. Different parameters related to water relations as well as mineral nutritients were measured. The exudation rate and relative water content were decreased but water saturation deficit was increased by salinity in both the varieties. In BARImung 2 plants, the exudation rate and relative water content were lower but water saturation deficit was higher than those in BUmung 2 at both 100 and $200 \mathrm{mM} \mathrm{NaCl}$ levels. Salinity also influenced the accumulation of $\mathrm{Na}, \mathrm{K}, \mathrm{Ca}$ and $\mathrm{Mg}$ in leaves, stems and roots of the two said mungbean varieties. Sodium accumulation was inceseased in all the plant-parts of both the varieties in the order of stem > root > leaf but in BUmung 2 the accumulation was lower than that of BARImung 2 except in root. Potassium accumulation deceresed in all parts of both the mungbean varieties but that was lower in BUmung 2 than that of BARImung 2. The contents of $\mathrm{Ca}$ and $\mathrm{Mg}$ in all the plant-parts increased more in BUmung 2 than those of BARImung 2 with the increase of salinity levels. All these results indicated that high salt tolerance in BUmung 2 was associated with its better water status, more or less uniform mineral nutrient $(\mathrm{Ca}$ and $\mathrm{Mg}$ ) distribution in different plantparts than that in BARImung 2.
\end{abstract}

Key words: $\mathrm{NaCl}$ salinity, Water relation, Ion accumulation, Mungbean varieties, Salinity tolerance

\section{Introduction}

Salinity is one of the major environmental stresses, which affects plant growth and development by disturbing water relations, creating imbalance in plant nutrition and affecting plant physiological and biochemical processes (Karim et al. 1993, Munns 2005). Under saline conditions plant suffers from osmotic shock due to lower osmotic potential in the soil solution (Orcutt and Nilsen 2000, Rahnama et al. 2010). Islam (2001) pointed out that relative water content (RWC), water saturation deficit (WSD), water retention capacity (WRC) and water uptake capacity (WUC) were affected by salinity in blackgram and mungbean.

*Author for correspondence: <talim_ju@yahoo.com>. 
At the whole plant level, salinity stress frequently induces an increase in $\mathrm{Na}$ and $\mathrm{Cl}$ contents as well as a decrease in $\mathrm{K}, \mathrm{Ca}, \mathrm{N}$ and Pi concentrations (Martinez and Lauchli 1994, Ahmad and Prasad 2012). Generally, Ca and K ions are decreased in plants under saline conditions (Al-Harbi 1995, James et al. 2011). In contrast, Ashraf and Rauf (2001) reported that under saline conditions concentrations of $\mathrm{Na}, \mathrm{K}$ and $\mathrm{Ca}$ increased significantly in all parts of the maize seedlings. Usually salinity tolerant variety of a crop shows better water relations, low accumulation of $\mathrm{Na}$, imbalance in the accumulation of nutrient elements, higher photosynthesis and finally better growth than those in salt sensitive ones. In glycophytes, salinity resistance is associated with a restriction of toxic ion absorption at the root level (Schachtman and Munns 1992) vis a vis minimum accumulation of $\mathrm{Na}$ and $\mathrm{Cl}$ in the shoot of the plant (Akita and Cabsulay 1990).

Leguminous crops are generally sensitive to salinity though there is considerable difference in salt tolerance between legume species (Maas and Hoffman 1977). Mungbean is an important glycophyte legume crop in Bangladesh. Despite the availability of a substantial number of reports on the effect of salinity on mungbean (Raptan et al. 2001, Kabir et al. 2005), the salt tolerance behavior and growth mechanisms of this crop remain unclear. To clarify salinity tolerance behavior in the present study a sensitive and a tolerant variety of mungbean were treated with $\mathrm{NaCl}$ salinity. The objectives of this study were to analyze the influence of salinity on water relations and mineral ion accumulation in different plant parts of two mungbean varieties differing in their salinity tolerance.

\section{Materials and Methods}

Two mungbean varieties, BARImung 2 (salinity sensitive) and BUmung 2 (salinity tolerant) were used for this experiment (Sultana et al. 2007). The plants were grown in pots in the research field of Botanical Garden of Jahangirnagar University. The physiological and biochemical analyses were carried out at the Plant Physiology and Plant Biochemistry laboratory of Botany Department, Jahangirnagar University and the Chemistry and Soil Science laboratory of Bangabandhu Sheikh Mujibur Rahman Agicultural University, Gazipur, Bangladesh. Each pot was filled with $12 \mathrm{~kg}$ of soil along with compost (made of grass, leaves and cowdung), one fourth of the soil by volume. Basal dose of fertilizers, $40 \mathrm{~kg} \mathrm{~N}, 60 \mathrm{~kg} \mathrm{P}$ and $40 \mathrm{~kg} \mathrm{~K}$ per hectare in the form of urea, triple super phosphate and muriate of potash, respectively were thoroughly mixed with the soil. The total amount of urea was applied in two splits. The soil samples were air dried, crushed and passed through a $3 \mathrm{~mm}$-pore-diameter sieve. The pots were kept under 
natural sunshine till harvesting (up to pre-flowering stage). There were six treatment combinations, which were comprised of two mungbean varieties and three levels of salinity. The three salinity levels were non-saline, control and $0 \mathrm{mM}$, and two salinity treatments, 100 and $200 \mathrm{mM} \mathrm{NaCl}$. The experiment was laid out in a completely randomized design (CRD) with three replications.

Four seeds of uniform size were directly sown in the pot and then the pots were watered for easy germination. After seedling establishment, only two better seedlings were allowed to grow in each pot. Then intercultural operation, weeding and pest control measures were taken as and when necessary. The germinated seedlings were watered up to 28th day of seedling emergence. Then watering was stopped. From the 32- to 42nd days after emergence (DAE), which was before flowering stage, the mungbean plants in each treated pot were irrigated with $100 \mathrm{ml}$ of $\mathrm{NaCl}$ solutions every day. Salt solutions were prepared artificially by dissolving 5.85 and $11.7 \mathrm{~g} / \mathrm{l}$ of commercially available $\mathrm{NaCl}$ with distilled water to make 100 and $200 \mathrm{mM} \mathrm{NaCl}$ solutions, respectively. Tap water was served as non-saline control. To study the physiological parameters, three plants of each treatment of each variety were taken for collecting data at pre-flowering stage.

Measurement of exudation rate: Exudation rate was measured at $5 \mathrm{~cm}$ above from the stem base of mungbean plant. At first dry cotton was weighed. A slanting cut on stem was made with a sharp knife. Then the weighed cotton was placed on the cut surface. The exudation of sap was collected from the stem for $1 \mathrm{hr}$ at normal temperature. The final weight of the cotton with sap was taken. The exudation rate was measured by deducting cotton weight from the sap containing cotton weight and expressed in per hour basis.

Measurement of plant water status: The fresh leaves of same sized and same aged of five plants from each treatment were carefully separated. Fresh weights of leaf segments were taken. The collected leaf segments were kept immersed in distilled water for $24 \mathrm{hrs}$ at room temperature in the dark. The turgid weights of those parts were then measured. Afterwards all the leaf materials were oven-dried at $80^{\circ} \mathrm{C}$ for $72 \mathrm{hrs}$ in order to take dry weight. The fresh, turgid and dry weights of the leaf segments were used to determine the relative water content (RWC) and water saturation deficit (WSD) following Sangakkara et al. (1996).

Analyses of mineral ions concentration in different plant-parts: For analysis of $\mathrm{Na}, \mathrm{K}, \mathrm{Ca}$ and $\mathrm{Mg}$, oven dried plant materials (leaves, stems and roots) at harvest were ground with a mortar and pestle. $500 \mathrm{mg}$ ground samples for each ion were taken in a conical flask with $5 \mathrm{ml}$ nitric-per chloric acid (nitric acid + perchloric acid, $5: 1$ ) dry-ashed at 200 $220^{\circ} \mathrm{C}$ for $2 \mathrm{hrs}$ at sand bath for digestion. After digestion distilled water was added, 
dissolved and made the digest up to $100 \mathrm{ml}$. Then $10 \mathrm{ml}$ solution and $2 \mathrm{ml}$ lanthanum chloride $\left(\mathrm{LaCl}_{3} .7 \mathrm{H}_{2} 0\right)$ were taken in a $100 \mathrm{ml}$ conical flask and by adding distilled water the solution was made up to $100 \mathrm{ml}$. Then liquid sample was taken in a vial test tube and absorbance of respective ions was measured with Atomic Absorption Spectrophotometer (Model 170-80, Hitachi) following the methods of Yamakawa (1992).

Data were analyzed statistically following randomized complete block design using ANOVA procedure in SAS statistical software.

\section{Results and Discussion}

The data on the effect of salinity on water status, exudation rate and water saturation deficit in mungbean varieties are presented in Table 1. Exudation rate in salt treated BARImung 2 plants was much lower than that of BUmung 2 at both 100 and $200 \mathrm{mM}$ $\mathrm{NaCl}$ levels. Compared to control plants, exudation rates of BUmung 2 decreased by 39.13 and $86.96 \%$, while those in BARImung 2 were decreased by 74.02 and $96.06 \%$ at 100 and $200 \mathrm{mM} \mathrm{NaCl}$, respectively (Table 1). Decreased exudation rate means lower water uptake by plants. Reduction in water uptake by plants due to salt stress has been reported by Islam (2001). Higher exudation rates in BUmung 2 disclosed that BUmung 2 plants could absorb more water than BARImung 2 under saline condition. Similar results were reported by Sangakkara et al. (1996) and Faruquei (2002).

Relative water content (RWC) was greater in plants grown at control than the plants grown under salinity stress (Table 1). The leaf of BUmung 2 and BARImung 2 showed identical RWC at control treatment. However, at the high salt concentration the leaf of BARImung 2 showed higher reduction $(45.25 \%)$ in RWC than that of BUmung 2 (32.63\%). Decreased in RWC due to salinity was reported by Kabir et al. (2005) in mungbean and Islam (2001) in mungbean and blackgram. It is well known that salinity decreases water potential of soil solution and plant cannot uptake water freely, and consequently RWC decreased (Orcutt and Nilsen 2000). In the present study, results indicated that BARImung 2 was found to suffer more from water stress than BUmung 2. The better water retention in BUmung 2 under saline condition obviously contributed for maintenance of higher plant growth than in BARImung 2. This result is in agreement with the report of White and Izquierdo (1991).

Water saturation deficit (WSD) showed an inverse trend of RWC (Table 1). WSD indicates the degree of water deficit in plants. Salinity increased the WSD in both the varieties compared to that of control treatment. However, the higher salt $(200 \mathrm{mM})$ 
treated plants of BARImung 2 showed relatively higher WSD (283.25\%) than that of BUmung 2 (258.04\%) over control. This finding reveals that BARImung 2 suffered more from water deficit especially at high salt concentration than BUmung 2. Similar results were reported by Islam (2001) and Kabir et al. (2005).

Table 1. Effect of $\mathrm{NaCl}$ salinity on exudation rate, relative water content (RWC) and water saturation deficit (WSD) of two mungbean varieties at pre-flowering stage.

\begin{tabular}{llllllll}
\hline Variety & $\begin{array}{l}\text { Salinity } \\
\text { level } \\
(\mathrm{mM})\end{array}$ & $\begin{array}{l}\text { Exudation } \\
\text { rate } \\
(\mathrm{mg} / \mathrm{min})\end{array}$ & $\begin{array}{l}\text { Changes } \\
\text { over } \\
\text { control } \\
(\%)\end{array}$ & $\begin{array}{l}\text { Relative } \\
\text { water } \\
\text { content } \\
(\mathrm{RWC})\end{array}$ & $\begin{array}{l}\text { Changes } \\
\text { over } \\
\text { control } \\
(\%)\end{array}$ & $\begin{array}{l}\text { Water } \\
\text { saturation } \\
\text { deficit } \\
(\text { WSD })\end{array}$ & $\begin{array}{l}\text { Changes } \\
\text { over } \\
\text { control } \\
(\%)\end{array}$ \\
\hline BARImung 2 & 0 & $2.54 \mathrm{a}$ & & $85.08 \mathrm{a}$ & & $10.33 \mathrm{~d}$ & \\
& 100 & $0.66 \mathrm{~d}$ & -74.02 & $60.13 \mathrm{c}$ & -29.33 & $34.46 \mathrm{c}$ & 233.59 \\
& 200 & $0.10 \mathrm{e}$ & -96.06 & $46.58 \mathrm{~d}$ & -45.25 & $39.59 \mathrm{~b}$ & 283.25 \\
BUmung 2 & 0 & $2.07 \mathrm{~b}$ & & $89.67 \mathrm{a}$ & & $14.92 \mathrm{~d}$ & \\
& 100 & $1.26 \mathrm{c}$ & -39.13 & $65.54 \mathrm{~b}$ & -26.91 & $39.87 \mathrm{~b}$ & 167.23 \\
& 200 & $0.27 \mathrm{e}$ & -86.96 & $60.41 \mathrm{c}$ & -32.63 & $53.42 \mathrm{a}$ & 258.04 \\
\hline
\end{tabular}

In a column followed by common small letters do not differ significantly at $5 \%$ level of significance.

Accumulation of mineral ions in different plant-parts: Results of $\mathrm{Na}$ accumulation of two mungbean varieties are presented in Table 2. Compared to control, $\mathrm{Na}$ accumulation was increased with increasing salinity levels for both the varieties. At high salt concentration however $\mathrm{Na}$ accumulation was higher (50 and 455.56\%) in leaf and stem parts of BARImung 2 than that in BUmung 2 (31.11 and 316.67\%). The tolerant variety, BUmung 2 accumulated less amount of $\mathrm{Na}$ in most of the plant parts except root compared to BARImung 2 (Table 2). Blum (1988) also reported that tolerant crop accumulated less amount of $\mathrm{Na}$ than susceptible one. The findings of Karim et al. (1992) in triticale and Raptan et al. (2001) in blackgram and mungbean indicated that tolerant cultivar maintained relatively larger $\mathrm{Na}$ in the root and a smaller amount in the shoot compared to the salt-susceptible cultivar. In contrast to shoot, Na concentration was greatly reduced in leaf. The reduction was higher in BARImung 2 compared to that of BUmung 2 (Table 2). This observation indicated that the translocation of $\mathrm{Na}$ from shoot to the leaf was regulated efficiently in BUmung 2 compared to BARImung 2. Probably this might be the reason for higher tolerance of BUmung 2 to salinity stress. 
Table 2. Effect of $\mathrm{NaCl}$ salinity on $\mathrm{Na}$ accumulation in two mungbean varieties at preflowering stage.

\begin{tabular}{llllllll}
\hline Variety & $\begin{array}{l}\text { Salinity } \\
\text { level } \\
(\mathrm{mM})\end{array}$ & $\begin{array}{l}\mathrm{Na} \\
\text { in leaf } \\
(\mathrm{mg} / \mathrm{g})\end{array}$ & $\begin{array}{l}\text { Changes } \\
\text { over } \\
\text { control } \\
(\%)\end{array}$ & $\begin{array}{l}\mathrm{Na} \text { in } \\
\text { stem } \\
(\mathrm{mg} / \mathrm{g})\end{array}$ & $\begin{array}{l}\text { Changes } \\
\text { over } \\
\text { control } \\
(\%)\end{array}$ & $\begin{array}{l}\mathrm{Na} \text { in } \\
\text { root } \\
(\mathrm{mg} / \mathrm{g})\end{array}$ & $\begin{array}{l}\text { Changes } \\
\text { over } \\
\text { control } \\
(\%)\end{array}$ \\
\hline BARImung 2 & 0 & $0.050 \mathrm{a}$ & & $0.063 \mathrm{~d}$ & & $0.605 \mathrm{c}$ & \\
& 100 & $0.068 \mathrm{~b}$ & 36.00 & $0.233 \mathrm{~b}$ & 269.84 & $0.783 \mathrm{~b}$ & 29.42 \\
& 200 & $0.075 \mathrm{c}$ & 50.00 & $0.350 \mathrm{a}$ & 455.56 & $0.947 \mathrm{a}$ & 56.53 \\
BUmung 2 & 0 & $0.045 \mathrm{a}$ & & $0.060 \mathrm{~d}$ & & $0.220 \mathrm{~d}$ & \\
& 100 & $0.054 \mathrm{a}$ & 20.00 & $0.168 \mathrm{c}$ & 180.00 & $0.663 \mathrm{c}$ & 201.36 \\
& 200 & $0.059 \mathrm{~b}$ & 31.11 & $0.250 \mathrm{~b}$ & 316.67 & $0.795 \mathrm{~b}$ & 261.36 \\
\hline
\end{tabular}

In a column followed by common small letters do not differ significantly at $5 \%$ level of significance.

Results of $\mathrm{K}$ accumulation in two mungbean varieties are presented in Table 3. The table shows that $\mathrm{K}$ accumulation was decreased by salinity in all parts of both the varieties of mungbean. With the increase in salinity from 0 to $200 \mathrm{mM}$, the reduction of $\mathrm{K}$ in all parts of BARImung 2 was higher compared to those of BUmung 2 (Table 3). At high salt concentration the reduction percencentage of $\mathrm{K}$ in leaf, stem and root of BARImung 2 were 28.50, 44.41 and 49.19 whereas those were 24.37, 37.90 and 36.78 in BUmung 2, respectively (Table 3). These results indicated that BUmung 2 acumulated higher $\mathrm{K}$ ion than that of BARImung 2.

Salinity induced reduction in $\mathrm{K}$ accumulation was reported in forage crops (Datta et al. 1996), and blackgram and mungbean (Raptan et al. 2001). Under saline conditions plant cells utilize $\mathrm{K}$ as a metabolite to maintain turgor to escape from osmotic shock (Blum 1988). In fact, the ability to maintain metabolically significant concentration of $\mathrm{K}$ may be essential for salt tolerance in glycophytes (Zhang and Blumward 2001, Daşgan et al. 2002).

Results of $\mathrm{Mg}$ accumulation of two mungbean varieties are presented in Table $4 . \mathrm{Mg}$ accumulation was increased almost in all parts except root with the increasing salinity levels for both the varieties. However, $\mathrm{Mg}$ accumulation was lower in BARImung 2 than that of BUmung 2. In leaves and stems BUmung 2 accumulated higher (27.37 and $21.39 \%) \mathrm{Mg}$ contents than those of BARImung 2 (15.32 and $14.51 \%$, respectively) at 200 $\mathrm{mM} \mathrm{NaCl}$. The decrease in $\mathrm{Mg}$ content in roots of BARImung 2 was higher (46.43\%) than that of BUmung 2 (22.63\%) over control (Table 4). These results indicated that BUmung 2 accumulated higher Mg than that of BARImung 2. Raptan et al. (2001) 
reported an increasing pattern of $\mathrm{Mg}$ accumulation in blackgram and mungbean under saline conditions, though Patil et al. (1995) did not find any influence of salinity on $\mathrm{Mg}$ accumulation in greengram. $\mathrm{Mg}$ accumulation in plant organs is probably helpful to maintain the osmoregulation to protect the plant cells from the osmotic shock caused by salinity (Greenway and Munns 1980).

Table 3. Effect of $\mathrm{NaCl}$ salinity on $\mathrm{K}$ accumulation in two mungbean varieties at preflowering stage.

\begin{tabular}{llllllll}
\hline Variety & $\begin{array}{l}\text { Salinity } \\
\text { level } \\
(\mathrm{mM})\end{array}$ & $\begin{array}{l}\mathrm{K} \text { in } \\
\text { leaf } \\
(\mathrm{mg} / \mathrm{g})\end{array}$ & $\begin{array}{l}\text { Changes } \\
\text { over } \\
\text { control } \\
(\%)\end{array}$ & $\begin{array}{l}\mathrm{K} \text { in } \\
\text { stem } \\
(\mathrm{mg} / \mathrm{g})\end{array}$ & $\begin{array}{l}\text { Changes } \\
\text { over } \\
\text { control } \\
(\%)\end{array}$ & $\begin{array}{l}\mathrm{K} \text { in } \\
\text { root } \\
(\mathrm{mg} / \mathrm{g})\end{array}$ & $\begin{array}{l}\text { Changes } \\
\text { over } \\
\text { control } \\
(\%)\end{array}$ \\
\hline BARImung 2 & 0 & $1.428 \mathrm{c}$ & & $1.448 \mathrm{c}$ & & $2.893 \mathrm{~b}$ & \\
& 100 & $1.207 \mathrm{c}$ & -15.48 & $1.243 \mathrm{c}$ & -14.23 & $2.122 \mathrm{c}$ & -26.65 \\
& 200 & $1.021 \mathrm{~d}$ & -28.50 & $0.805 \mathrm{~d}$ & -44.41 & $2.033 \mathrm{c}$ & -49.19 \\
BUmung 2 & 0 & $2.692 \mathrm{a}$ & & $3.166 \mathrm{a}$ & & $3.622 \mathrm{a}$ & \\
& 100 & $2.442 \mathrm{~b}$ & -9.29 & $2.866 \mathrm{~b}$ & -9.48 & $2.948 \mathrm{~b}$ & -18.61 \\
& 200 & $2.036 \mathrm{~b}$ & -24.37 & $1.966 \mathrm{c}$ & -37.90 & $2.290 \mathrm{c}$ & -36.78 \\
\hline
\end{tabular}

In a column followed by common small letters do not differ significantly at $5 \%$ level of significance.

Table 4. Effect of $\mathrm{NaCl}$ salinity on $\mathrm{Mg}$ accumulation in two mungbean varieties at preflowering stage.

\begin{tabular}{llllllll}
\hline \multirow{2}{*}{ Variety } & $\begin{array}{l}\text { Conc. of } \\
\mathrm{NaCl} \\
(\mathrm{mM})\end{array}$ & $\begin{array}{l}\mathrm{Mg} \text { in } \\
\text { leaf } \\
(\mathrm{mg} / \mathrm{g})\end{array}$ & $\begin{array}{l}\text { Changes } \\
\text { over } \\
\text { control } \\
(\%)\end{array}$ & $\begin{array}{l}\mathrm{Mg} \text { in } \\
\text { stem } \\
(\mathrm{mg} / \mathrm{g})\end{array}$ & $\begin{array}{l}\text { Changes } \\
\text { over } \\
\text { control } \\
(\%)\end{array}$ & $\begin{array}{l}\mathrm{Mg} \text { in } \\
\text { root } \\
(\mathrm{mg} / \mathrm{g})\end{array}$ & $\begin{array}{l}\text { Changes } \\
\text { over } \\
\text { control } \\
(\%)\end{array}$ \\
\hline BARImung 2 & 0 & $0.359 \mathrm{c}$ & & $0.317 \mathrm{c}$ & & $0.659 \mathrm{a}$ & \\
& 100 & $0.398 \mathrm{bc}$ & 10.86 & $0.343 \mathrm{c}$ & 8.20 & $0.577 \mathrm{~b}$ & -12.44 \\
& 200 & $0.414 \mathrm{~b}$ & 15.32 & $0.363 \mathrm{bc}$ & 14.51 & $0.353 \mathrm{~d}$ & -46.43 \\
BUmung 2 & 0 & $0.380 \mathrm{bc}$ & & $0.402 \mathrm{~b}$ & & $0.486 \mathrm{c}$ & \\
& 100 & $0.468 \mathrm{a}$ & 23.16 & $0.458 \mathrm{a}$ & 13.93 & $0.437 \mathrm{~b}$ & -10.08 \\
& 200 & $0.484 \mathrm{a}$ & 27.37 & $0.488 \mathrm{a}$ & 21.39 & $0.376 \mathrm{~d}$ & -22.63 \\
\hline
\end{tabular}

In a column followed by common small letters do not differ significantly at $5 \%$ level of significance. 
Table 5. Effect of $\mathrm{NaCl}$ salinity on $\mathrm{Ca}$ accumulation in two mungbean varieties at preflowering stage.

\begin{tabular}{llllllll}
\hline Variety & $\begin{array}{l}\text { Conc. of } \\
\mathrm{NaCl} \\
(\mathrm{mM})\end{array}$ & $\begin{array}{l}\text { Ca in } \\
\text { leaf } \\
(\mathrm{mg} / \mathrm{g})\end{array}$ & $\begin{array}{l}\text { Changes } \\
\text { over } \\
\text { control } \\
(\%)\end{array}$ & $\begin{array}{l}\text { Ca in } \\
\text { stem } \\
(\mathrm{mg} / \mathrm{g})\end{array}$ & $\begin{array}{l}\text { Changes } \\
\text { over } \\
\text { control } \\
(\%)\end{array}$ & $\begin{array}{l}\mathrm{Ca} \text { in } \\
\text { root } \\
(\mathrm{mg} / \mathrm{g})\end{array}$ & $\begin{array}{l}\text { Changes } \\
\text { over } \\
\text { control } \\
(\%)\end{array}$ \\
\hline BARImung 2 & 0 & $3.680 \mathrm{c}$ & & $2.160 \mathrm{c}$ & & $3.270 \mathrm{a}$ & \\
& 100 & $4.640 \mathrm{~b}$ & 26.09 & $2.620 \mathrm{~b}$ & 21.30 & $1.860 \mathrm{~b}$ & -43.12 \\
& 200 & $5.240 \mathrm{ab}$ & 42.39 & $3.000 \mathrm{a}$ & 38.89 & $1.466 \mathrm{c}$ & -55.17 \\
BUmung 2 & 0 & $3.223 \mathrm{c}$ & & $0.979 \mathrm{~d}$ & & $1.375 \mathrm{~cd}$ & \\
& 100 & $4.349 \mathrm{~b}$ & 34.94 & $1.738 \mathrm{c}$ & 77.53 & $1.225 \mathrm{~d}$ & -10.91 \\
& 200 & $5.540 \mathrm{a}$ & 71.89 & $2.560 \mathrm{~b}$ & 161.49 & $1.171 \mathrm{~d}$ & -14.84 \\
\hline
\end{tabular}

In a column followed by common small letters do not differ significantly at $5 \%$ level of significance.

Results of $\mathrm{Ca}$ accumulation of two mungbean varieties are presented in Table 5. The table shows that $\mathrm{Ca}$ accumulation was increased in leaves and stems with the increasing salinity levels for both the varieties, except roots. At high concentration of $\mathrm{NaCl}(200$ $\mathrm{mM}$ ), the percentages of $\mathrm{Ca}$ ion in leaf and stem of BUmung 2 were 71.89 and 161.49 whereas those in BARImung 2 were 42.39 and 38.89, respectively (Table 5). Similar results were reported by Raptan et al. (2001) in blackgram and mungbean. Salinity induced reduction of calcium uptake was reported by Patil et al. (1995) in greengram. Blum (1988) found that like some other elements $\mathrm{Ca}$ also acts as metabolite to protect plant cells from the osmotic shock in different crops under saline stress. The increase in $\mathrm{Ca}$ contents in leaves and stems was higher in BUmung 2 than those of BARImung 2 and the decrease of $\mathrm{Ca}$ content in roots was higher in BARImung 2 than that of BUmung 2 over control (Table 5). These results revealed that BUmung 2 accumulated higher $\mathrm{Ca}$ than that of BARImung 2 which indicates the high tolerance of BUmung 2 to salinity stress. Lutts et al. (1996) reported that Ca content was decreased with salinity in saltsensitive genotypes while they remained at constant levels in salt-resistant ones.

\section{References}

Ahmad, P. and M.N.V. Prasad, 2012. Abiotic Stress Responses in Plants: Metabolism, Productivity and Sustainability. New York, NY: Springer.

Akita, S. and G.S. Cabsulay. 1990. Physiological basis of differential response to salinity in rice cultivars. Plant Soil. 123: 277-295

Al-Harbi, A.R. 1995. Growth and nutrient composition of tomato and cucumber as affected by sodium chloride salinity and supplemental calcium. J. Plant Nutri. 18: 1403-1416. 
Ashraf, M. and H. Rauf. 2001. Inducing salt tolerance in maize (Zea mays L.) through seed priming with chloride salts: Growth and ion transport at early growth stages, Acta Physiol. Plant. 23: 407-414.

Blum, A. 1988. Salinity resistance. In: Plant Breeding for Stress Environments. CRC Press (Florida), pp. 163-176

Daşgan, H.Y., H. Aktaş, K. Abak and I. Cakmak. 2002. Determination of screening techniques to salinity in tomatoes and investigation of genotype responses. Plant Sci. 163: 695-703.

Datta, K.S., A. Kumar, S.K. Verma and R. Angrish. 1996. Effects of salinity on water relations and ion uptake in three tropical forage crops. Indian J. Plant Physiol. 1(2): 102-108

Faruquei, M.A.B. 2002. Effect of water stress on morpho-physiological changes in Vigna radiata L.Wilczek grown under saline conditions. An M.S. thesis. Dept. of Agronomy, BSMRAU, Salna, Gazipur, Bangladesh.

Greenway, H. and R. Munns. 1980. Mechanisms of salt tolerance in non-halophytes. Ann. Rev. Plant Physiol. 31: 149-190.

Islam, M.S. 2001. Morpho-physiology of blackgram and mungbean as influenced by salinity. An M.S. thesis. Dept. of Agronomy, BSMRAU, Salna, Gazipur, Bangladesh.

James, R.A., C. Blake, C.S. Byrt and R. Munns. 2011. Major genes for Na+ exclusion, (Nax1 and Nax2 wheatHKT1;4 and HKT1;5), decrease $\mathrm{Na}^{+}$accumulation in bread wheat leaves under saline and water logged conditions. J. Exp. Bot. 62: 2939-2947.

Kabir, M.E., A. Hamid, M. Haque, E. Nawata and M.A. Karim. 2005. Effect of nitrogen fertilizer on salinity tolerance of mungbean (Vigna radiata L. Wilczek). Jap. J. Trop. Agric. 49: 119125

Karim, M.A., E. Nawata and S. Shigenaga. 1993. Effects of salinity and water stress on the growth, yield and physiological characteristics in hexaploid triticale. Japan J. Crop. Agric Sci. 37: 4652

Karim, M.A., N. Utsonomiya and S. Shigenaga. 1992. Effect of sodium chloride on the germination and growth of hexaploid Triticale at early seedling stage. Japan J. Crop Sci. 61: 279-284

Lutts, S., J.M. Kinet and J. Bouharmon. 1996. Effects of salt stress on growth, mineral nutrition and proline accumulation in relation to osmotic adjustment in rice (Oryza sativa L.) cultivars differing in salinity resistance. Plant Growth Regulation, 19: 201-218

Maas, E.V. and G.J. Hoffman. 1977. Crop Salt Tolerance-Current Assessment. Journal of the Irrigation and Drainage Division, American Society of Civil Engineers, 103: 115-134

Martinez, V. and A. Lauchli. 1994. Salt-induced inhibition of phosphate uptake in plants of cotton (Gossypium hirsutum L.). New Phytol. 126: 609-614

Munns, R. 2005. Genes and salt tolerance: Bringing them together. New Phytol. 167: 645-663

Orcutt, D.M. and E.T. Nilsen. 2000. The physiology of plants under stress. John Wily and Sons Inc., 605 3rd Evenue, New York, 10158-0012, USA, pp. 177-235

Patil, S.L., C.S. Hunshal, D.P. Vishwanath and V.P. Chimmand. 1995. Effect of use of saline water to supplement good water on the uptake of nutrients by greengram on black soil. Indian J. Agric. Res. 29: 181-187

Rahnama, A., R.A. James, K. Poustini and R. Munns. 2010. Stomatal conductance as a screen for osmotic stress tolerance in durum wheat growing in saline soil. Funct. Plant Biol. 37: 255-263

Raptan, P.K., A. Hamid, Q.A. Khaliq, A.R.M. Solaiman, J.U. Ahmed and M.A. Karim. 2001. Salinity tolerance of blackgram and mungbean: I. Dry matter accumulation in different plant parts. II. Mineral ions accumulation in different plant parts. Korean J. Crop Sci. 46: 380-394

Sangakkara, U.R., U.A. Hartwig and J. Nosberger. 1996. Responses of root branching and shoot water potentials of French bean (Phaseolus vulgaris L.) to soil moisture and fertilizer potassium. J. Agron. Crop. Sci. 177: 165-173 
Schachtman, D.P. and R. Munns, 1992. Sodium accumulation in leaves of Triticum species that differ in salt tolerance. Aust. J. Plant Physiol. 19: 331-340

Sultana, M.S., M.A. Karim, F. Hossain and M.T. Hossain. 2007. Effect of $\mathrm{NaCl}$ on germination and growth of mungbean varieties. Bangladesh J. Life Sci. 19(2): 1-8

White, J.W. and J. Izquierdo. 1991. Physiology of yield potential and stress tolerance. In: A. van Schoonhoven \& O. Voysest (Eds.), Common Beans. Research for Cop Improvement, pp. 287 382. CAB Int CIAT, Colombia

Yamakawa, T. 1992. Laboratory Methods for Soil Science and Plant Nutrition JICA-IPSA Project Publication, IPSA, Gazipur, Bangladesh, pp. 1-14.

Zhang, H.X. and E. Blumward. 2001. Transgenic salt-tolerant tomato plants accumulate salt in foliage but not in fruit. Nat. Biotechnol. 9: 765-768.

(Revised copy received on 23.04.2019) 